\title{
What Should We Do for E-government in Nepal and How? An AHP Approach
}

\author{
Devid Kumar Basyal* and Jin-Wan Seo**
}

\begin{abstract}
As E-government has been referred to as the use of ICTs to transform government by making it more accessible, effective and accountable, the Nepal government has taken some positive initiatives for its development. However, according to the UN evaluation, the current E-government level in Nepal is still very poor. This paper raised two research questions: what the major problems of E-government implementation in Nepal are and which problem(s) should be solved first. For this purpose, the Analytic Hierarchy Process (AHP) method was used to rank the problems in hierarchical order. This study finds that among the various problems of E-government implementation in Nepal, a lack of strong leadership and government will, political-administrative instability, and resistance to change within organizations were again highlighted as the most severe ones by experts.
\end{abstract}

Keywords: E-government in Nepal, E-government Implementation, E-government Readiness, AHP Analysis

\section{INTRODUCTION}

E-government can be referred to as the use and application of information technologies in public administration to streamline and integrate workflows and processes, to effectively manage data and information, enhance public service delivery, as well as to expand communication channels for the engagement and empowerment of people (United Nations, 2014). E-government is understood as the use of emerging ICTs such

\footnotetext{
* Devid Kumar Basyal is a PhD candidate at Department of Public Administration, Incheon National University, Incheon, South Korea. E-mail: devidbasyal@gmail.com.

** Jin-Wan Seo $(\mathrm{PhD})$ is a professor at Department of Public Administration, Incheon National University, Incheon, South Korea. Prof. Seo is the corresponding author of this article. Email: sjinwan@inu.ac.kr.
}

Manuscript received September 5, 2016; out for review October 22, 2016; review completed December 18, 2016; accepted December 20, 2016.

The Korean Journal of Policy Studies, Vol. 31, No. 3 (2016), pp. 47-74.

(C) 2016 by the GSPA, Seoul National University 
as the Internet, World Wide Web (www) and mobile phones to deliver information and services to citizens and businesses (Iqbal \& Seo, 2008). E-government is not simply a matter of giving government officials computers or automating old practices. E-government utilizes technology to accomplish reform by fostering transparency, eliminating distance and other divides and empowering people to participate in the political processes that affect their lives (World Bank, 2002). Hence, E-government is not a new subject. Rather, it is a new concept of government with the use of ICTs to transform government by making it more accessible, effective and accountable. As a result, it helps to ensure E-governance at large.

The Government of Nepal (GoN) has been taking different initiatives for the development of E-government in Nepal for a long time. However, there seems to have been significant improvement after the restoration of democracy in 1990 as the democratic government has adopted policies of economic liberalization, globalization and privatization. With the establishment of the Ministry of Science and Technology in 1996, this sector was also acknowledged as an important part of development. The First IT Policy (2000) which was amended in 2004 and again replaced by IT policy 2010, has also created a solid foundation for the development of E-government which has allowed many private firms and institutions to work in the IT sector. The High Level Commission for Information Technology (HLCIT) in 2003, Cyber Law in 2004, Electronic Transaction Act in 2006 and E-government Master Plan (2007-2011) etc. were some examples which show that the government placed the IT sector as a top priority.

However, United Nations E-government Surveys indicate that Nepal's position in E-government development has been gradually deteriorating from the first survey in 2003 to the latest one in 2014. In view of the E-participation Index (EPI), Nepal's situation is unsatisfactory. Netherlands and the Republic of Korea with the highest EPI (1.0) were in first place whereas Uruguay with 0.9804 ranked in the third place in 2014. The world average was 0.3947. Nepal with an EPI of 0.2941 placed 110th in 2014.

Despite some positive initiatives taken by the Government of Nepal for the development of E-government and the ICT sector, Nepal still lags behind. Even though the importance of ICT in both sectors (government and private) was realized in the 1990s and the first IT policy was formulated in 2000, Nepal has not succeeded in the development of E-government. UN E-government survey data and other indicators validate its poor condition. As in other underdeveloped and developing countries, there are many barriers to E-government implementation in Nepal. After a review of relevant literature, the most frequently raised problems in the course of E-government implementation were identified and categorized as one of four -Technological, Political-Administrative, Socio-cultural and Economic. Additionally, under these four main dimensions or 
categories, fifteen problems were identified again as frequently cited by scholars.

This paper aims at discussing three main issues, explicitly: what is the situation of E-government in Nepal, what kinds of problems are common in developing countries like Nepal and what kinds of problems should be prioritized in hierarchical order and solved first. For this purpose, we use UN E-government survey data from 2003 to 2014 to explain the situation of E-government in Nepal. Similarly, some pertinent literatures are reviewed to address the second issue of e-government implementation. Lastly, for the ranking of problems, we employ the Analytic Hierarchy Process (AHP) Method. In other words, after analyzing the present situation of E-government and finding major problems, this papers tries to rank them using the Analytic Hierarchy Process (AHP) method taking experts' opinion. The primary reason for ranking problems is that Nepal is still an economically poor country and lacks abundant resources to invest in developmental works. As there exists a scarcity of necessary resources and required technology, Nepal cannot solve all problems at a time. The apparent example is failure of the E-government Master Plan 2007-2011 (Rupakhetee \& Hashmati, 2011). So by comparing the major problems, we hope that it gives a guideline to identify ranking problems in order. As a result, it will give a guideline to political leaders, top bureaucrats and other concerned academicians and policy analysts to solve the problems of Egovernment implementation in Nepal in a hierarchical order.

\section{HISTORY OF E-GOVOERNMENT AND CURRENT SITUATION IN NEPAL}

\section{Government Efforts: Historical Approach}

Even though the history of E-government is still young, the Government of Nepal has made some efforts for the development of this sector.

\section{Before 1990}

Although there was no significant development in this sector until 1990, the year 1971 can be regarded as a Landmark Year in terms of Nepal's exposure to ICT when the government used a computer (IBM 1401) in its national population census program (Rupakhetee \& Heshmati, 2011). The Communications Corporation Act 1971 aided to establish the Nepal Telecommunication Corporation in 1975 as a fully state-owned corporation which ultimately transferred into Nepal Telecom; a public limited company in 2004 (Nepal Telecom, 2015). The establishment of the National Computer Center 
(NCC) in 1974 with the aim of disseminating IT training and knowledge all over Nepal was another initiative which had the unfortunate fate of dissolving in 1996. Data System International (DSI), a first international software development company, was established in 1982 with the aim of software development and the year 1985 witnessed the distribution of personal computers (Dhami \& Futo, 2010).

\section{Between 1990 and 2000}

This decade observed noteworthy improvements and changes in the IT sector (i.e. mainly after the restoration of democracy in 1990). In this period, many public policies and programs were reformed as per the spirit of the democratic government. In 1990, there was liberalization on imports of IT equipment (Dhami \& Futo, 2010). The Computer Association of Nepal (CAN) was formed in 1992 and later registered as the Federation of Computer Association of Nepal (CAN Federation) in January 2015 with the involvement of professionals, specialists, institutions and related organizations from the ICT sector in Nepal which is an autonomous, non-political, nonpartisan, nonprofitable and service oriented sector (CAN, 2015). In the same year 1992, the Mercantile Communication Pvt. Ltd. (MCPL) started the first commercial e-mail service (Rupakhetee \& Hashmati, 2011). So there does not seem to have been any remarkable progress in the field of ICT until 1995. When the Ministry of Science and Technology was formed in 1996, this sector was also acknowledged as an important part of development, particularly during 1997-2004, which happened to be an important time when a number of policy and regulatory measures were prepared and implemented in the ICT sector (Rupakhetee \& Hashmati, 2011). In 1996, the Telecommunication act was enacted as a result. Nepal Telecommunication Authority, as an independent body, was established in 1997 (NTA, 2015).

\section{After 2000 to the Present}

With the declaration of the first information technology (IT) policy in 2000, Nepal moved into a scientific and systematic way of ICT development. IT policy 2000 clearly proclaimed policies for a regulatory framework, infrastructure development, E-government content and applications, human resource development and organizations. Its vision was 'to place Nepal on the Global Map of Information Technology within the next five years with three clear objectives: i.e. to make information technology accessible to the general public and increase employment through this means, to build a knowledge-based society, to establish knowledge-based industries (MoSTE, 2000). The formation of the National Information Technology Center (NITC) under the 
Ministry of Science and Technology in 2001 was another remarkable work in the course of ICT development in Nepal. The National Strategy Paper on ICT with the initiative of National Planning Commission (NPC) in 2002 added another brick to the wall of ICT's further advancement (Dhakal, 2010). With the constitution of the High Level Commission for Information Technology (HLCIT) in 2003, the prime importance of the ICT sector was made clear. Likewise, in 2004, the Cyber Law was enacted and the IT Policy 2000 was again revised. The Electronic Transaction Act was introduced in 2006 and the same year witnessed the establishment of IT Park at Dhulikhel which sadly could not begin operation for long time and is now closed. With the aim of development and implementation of an electronic transaction system and delivery of service to citizens and businesses, the E-government Master Plan (e-GMP) was prepared by the government in 2006, supported by the Korea IT Industry Promotion Agency (KIPA). e-GMP (2007-11), which was undertaken by High Level Commission for Information Technology (HLCIT), has provided a framework for moving towards fullfledged E-government in the country (Rupakhetee \& Hashmati, 2011). To substantiate the work, HLCIT and KIPA signed the MOU on consulting for the setting up of Egovernment master plan development and its proper implementation. As a result, the Government Integrated Data Center (GIDC) administrated by the National Information Technology Center (NITC) was built, but this center is also still in its first phase. In 2008, ADSL technology was introduced (NT, 2015).

In the year 2010, a new Information Technology (IT) Policy was launched replacing the previous IT Policy 2000. The vision of IT policy 2010 is "To establish Nepal in the world map of information technology and transfer into knowledge-based society" (MoST, 2010). Its mission is to achieve social and economic development goals including good governance, poverty reduction with the proper use of information technology in Nepal. Similarly, the goal of current IT policy is poverty reduction through the maintaining of social and economic development goals with the use of information technology. To fulfil the afore-mentioned vision, mission and main goal, it has set up six other goals and twenty-nine policies. ${ }^{1}$ And recently, the Nepal Government has formed an ICT council based on the cabinet decision of May 12, 2016 comprising 23 members where the PM will be the president, ministers from Ministry of Information and Com-

1. Key institutions and organizations dealing with ICTs in Nepal are as follow: Ministry of Science and Technology (MoST), High Level Committee for Information Technology (HLCIT), National Information Technology Center (NITC), Nepal Telecom Authority, Internet Service Providers' Association of Nepal (ISPAN), Nepal Telecom (NT), United Telecom Limited (UTL), N-cell, Computer Association of Nepal (CAN), and E-Networking, Research and Development (ENRD). 
munications and Ministry of Science and Technology will be the two vice-presidents and other members from top bureaucrats and experts, says Dinesh K. Thapaliya, secretary, Ministry of Information and Communication.

\section{Current Situation of E-government in Nepal: Based on UN Evaluation}

Successful implementation of E-government initiatives delivers various opportunities such as new services, more citizen involvement in public affairs and an improved information infrastructure (Seo \& Hasan, 2015). Different scholars and institutions have developed their own models and respective characteristics of each phase. Of these, the World Bank three-stage model, the UN's five-stage model and Gartner's four-stage model are commonly used. UNASPA (2001) suggested five stages of an E-government model: Emerging Presence, Enhanced Presence, Interactive Presence, Transactional Presence, and Seamless or Fully Integrated Presence.

Most advanced nations have developed highly interactive government web sites to act as a portal to connect users and service providers, and the interaction takes place at a more sophisticated level (Interactive Presence), allowing users to conduct complete and secure transactions, such as renewing visas, obtaining passports and updating birth and death records through a single government web site (Transactional Presence). After that, they have tried to reach the final stage, Seamless or Fully Integrated Presence, which is the optimum level of E-government development. In this stage, governments utilize a single and universal web site to provide a one-stop portal in which users can immediately and conveniently access all kinds of available services. However, a majority of nations in the world still remain within one of the first three stagesEmerging Presence, Enhanced Presence, and Interactive Presence. They have significantly progressed in E-government since they started. However, Nepal's situation seems inconsistent, having mainly deteriorated in later years in comparison to its initial situation. After analyzing the United Nations data discussed below and looking at the real situation of E-government in the country, we find that Nepal is still in the initial stage, Emerging Presence, in which a single or few independent government web sites provide formal but limited and static information. Government web sites are not ready to provide dynamic, specialized and regularly updated information.

As another way to understand and evaluate the situation of E-government in the member nations, the UN E-government Survey has developed two different indices; namely the E-government Development Index (EGDI) and the E-participation Index (EPI). ${ }^{2}$ The Republic of Korea with an EDGI value of 0.9462 stood in the first position

2. The EDGI is a composite measure of three important dimensions of E-government, namely: 
Figure 1. E-government Development Index (EGDI)

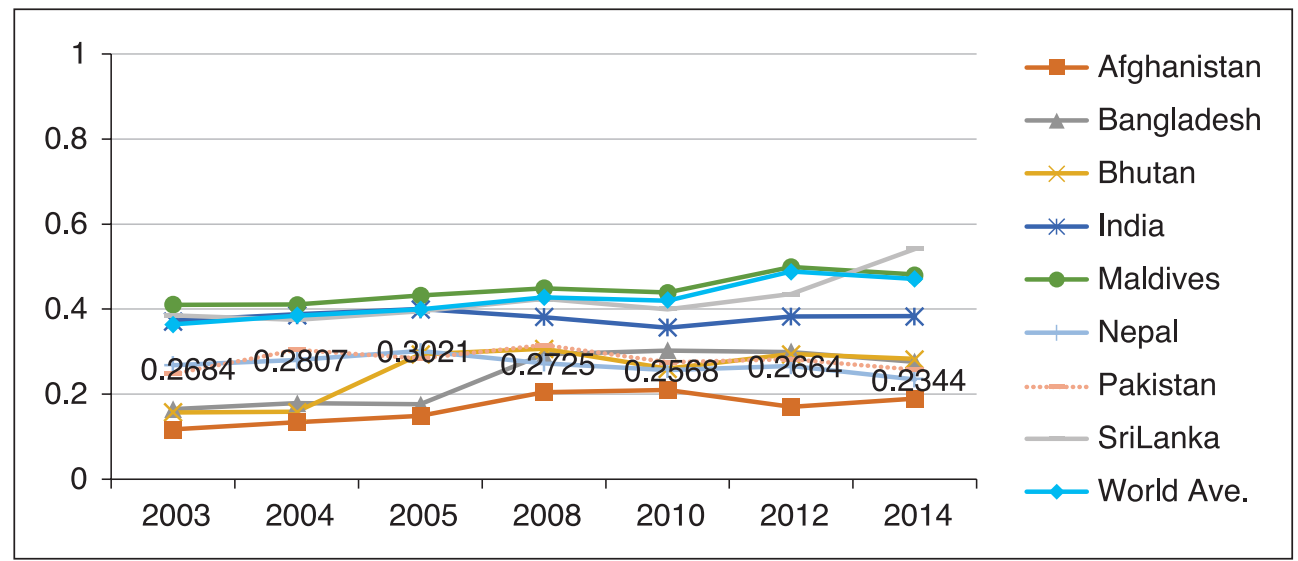

Source: United Nations E-Govt. Surveys

in 2014. Similarly, Australia and Singapore placed second and third respectively with great improvement after 2012. The world average of EGDI in 2014 was 0.4712 and Nepal's value was 0.2344 with a ranking of 165 th.

The EGDI value of Nepal throughout the surveys seems uneven. In the first survey in 2003, it was 0.2684 which gradually increased to 0.2807 and 0.3021 in the consecutive survey years 2004 and 2005. After 2008, the value started to plummet and in the survey of 2014, it was just 0.2344 which is the lowest across all surveys. It means that Nepal's current E-government development situation is getting worse than that of previous years which is a grave concern.

As we can see from the above time series line graph, Nepal's position in the EGDI ranking is gradually deteriorating from the first survey in 2003 to the latest one of 2014 except in the survey year 2005. Out of 193 UN member countries, Nepal was

provision of online services (OSI), telecommunication connectivity (TII) and human capacity (HCI) (United Nations, 2014). Each index mentioned above is also a composite measure of different components. For example, the Online Service Index (OSI) assesses two major things, i.e. technical features of national websites and E-government policies and strategies applied in general and by specific sectors for delivery of services. Similarly, the Telecommunication Infrastructure Index (TII) consists of five major components; namely mobilecellular subscriptions (per 100), fixed-telephone subscriptions (per 100), individuals using internet (\% population), fixed (wired)-broadband subscriptions (per 100) and wireless broadband subscriptions (per 100). Likewise, the Human Capital Index (HCI) is comprised of four components: gross enrolment ratio (\%), adult literacy (\%), expected year of schooling and mean year of schooling. 
Figure 2. E-government Development Index-EGDI (Rank)

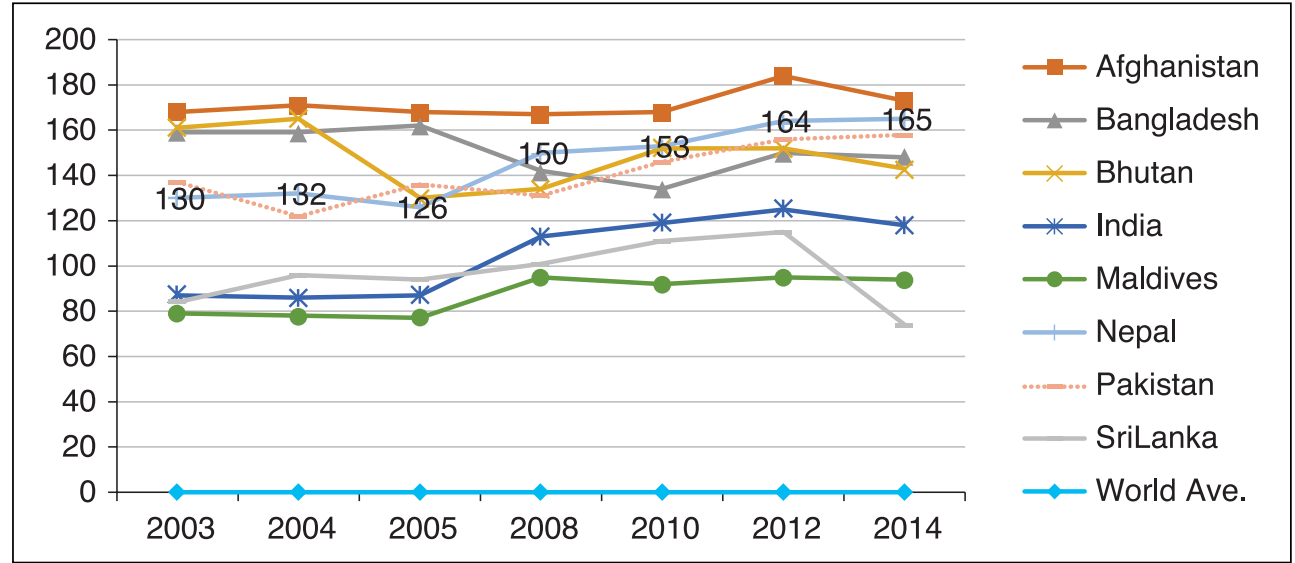

Source: United Nations E-Gov. Surveys

ranked in 130th place in 2003 which gradually started to decline in the following years. It slightly improved its position in 2005, remaining in 126th place. Thereafter it has continuously decreased. As a result, it plunged into 165th position in 2014. Except Afghanistan, the other SAARC nations are gradually improving their situation in terms of E-government development.

E-participation, on the other hand, is the process of engaging citizens through ICTs in policy and decision-making in order to make public administration participatory, inclusive, collaborative and deliberative for intrinsic and instrumental ends (United Nations, 2014). ${ }^{3}$ The Netherlands and the Republic of Korea with highest EPI (1) were in the first place whereas Uruguay with 0.9804 ranked in the third place in 2014. The world average was 0.3947 . Nepal with EPI 0.2941 placed in 110th position in 2014.

The values of EPI of Nepal during seven different survey years also show a zigzag trend. In the first survey in 2003 , the value was 0.1379 which became $0.0656,0.0794$, 0.0277, 0.0571, and 0.0263 in the years 2004, 2005, 2008, 2010 and 2012 respectively. But there seemed to be an astonishing rise in the last survey when its EPI changed to 0.2941 in 2014. The development trend of the EPI of almost all other SAARC countries

3. The E-participation index (EPI) is developed as an additional index to the UN E-government Survey. It extends the dimension of the survey by focusing on three major components; einformation sharing, e-consultation and e-decision-making. As EPI is a qualitative assessment, the value of EPI attempts to capture the e-participation performance of countries relative to one another at a particular point in time. 
Figure 3. E-participation Index (EPI)

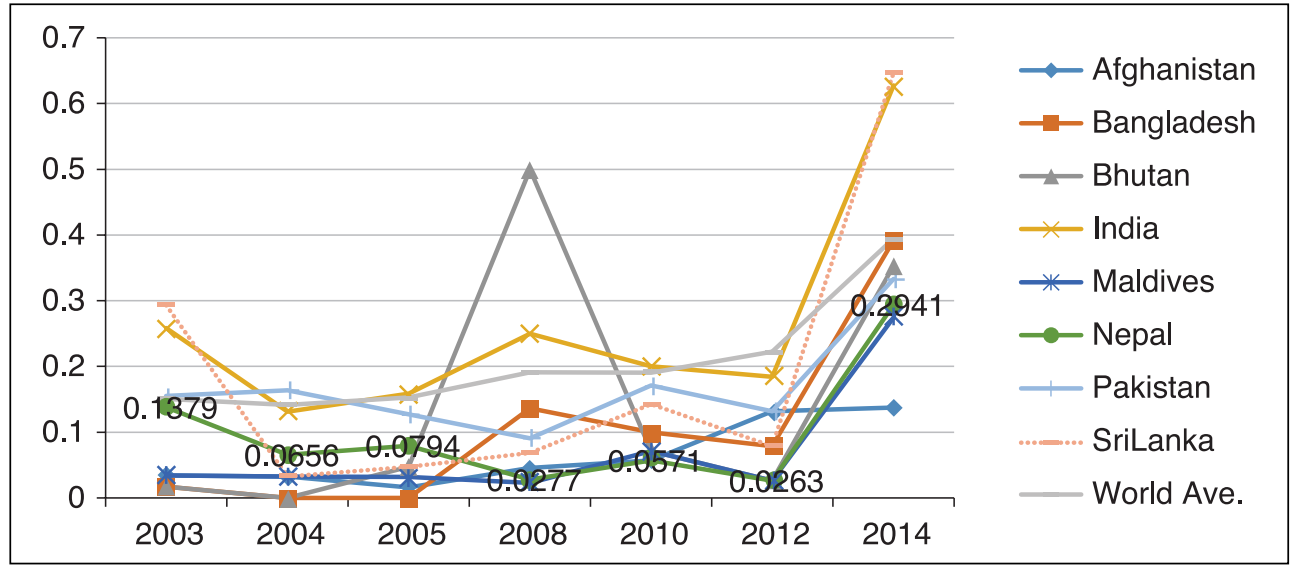

Source: United Nations E-Gov. Surveys

looks similar expect for Bhutan. There seemed an unusual and sky-diving rise of Bhutan in 2008 with the EPI value 0.5000.

In terms of e-participation ranking, the situation of Nepal is inconsistent. In 2003, Nepal was in the 61st position. Then it declined to 75th, 73rd and 152nd in 2004, 2005 and 2008 respectively. From 2008 to the present, however, though the trend seems to be gradually improving, Nepal's position is still not satisfactory. In 2014, Nepal stands in 110th place. Among SAARC member nations, the EPI trend of Bhutan seems quite volatile. In 2003, it placed 123rd which changed to 152nd in 2004. Unbelievably, it

Figure 4. E-participation (Rank)

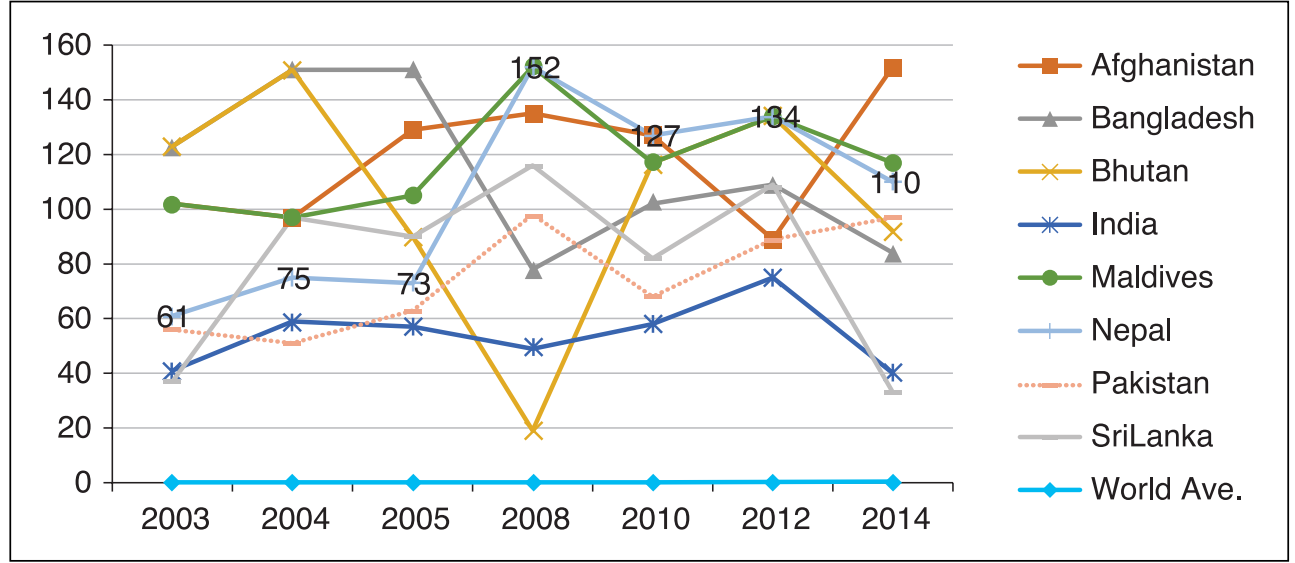

Source: United Nations E-Gov. Surveys 
stood in 19th position in 2008; then its position again went up in the later years. At present, Bhutan is 92 nd out of 193 countries.

\section{PROBLEMS AND/OR BARRIERS OF E-GOVERNMENT IMPLEMENTATION}

The variety and complexity of E-government initiatives implies the existence of a wide range of challenges and barriers to its implementation and management (Alshehri $\&$ Drew, 2010). Analyzing the different stages of E-government development and the value of EDGI and EPI, Nepal is far behind in the area of E-government development. A fully scaled implementation of E-government requires more than a simple automation of existing processes (Pavlichev, 2004). In a study of Tanzania, Lupilya and Jung (2015) considered three main factors related to E-government transformation. Their study found that a reluctance to promote transparency and accountability, an avalanche of technology and an illusion of innovation and technological misfortune led to a stagnant e-government process....(Lupilya and Jung (2015)). As in other under-developed countries, Nepal's E-government sector is developing at a snail's pace. Despite some positive initiatives taken by the Government of Nepal in the course of E-government improvement, there remain many problems. These problems are sometime also called challenges or barriers. Previous related literature (articles and books), has stated many problems associated with E-government implementation but they were not placed in a proper order or related categories. However, by analyzing them, it has been found that technical, political-administrative, social-cultural, and economic are some major areas which were discussed frequently. To develop the research framework, these are identified as main categories or major factors within which there are other problems/barriers which can be named as variables.

\section{Technological Problems}

The technological category or dimension of problems is one of the major ones in the course of E-government enhancement. The full benefit of E-government will be realized only if organizational changes accompany technological changes (Pavlichev, 2004). ICT infrastructure offers a variety of technologies to support an institution in running efficiently and effectively. These are essential and integral parts of an organization and they include hardware, software, networking and implementation. Development of an effective telecommunication infrastructure is primary prerequisite in order to deliver E-government services. And again, successful E-government implementation 
would depend on how the capacities of various infrastructures are structured and how they are capitalized with an integrated focus (Alshehri \& Drew, 2010).Unreliable IT infrastructure will contribute to the degradation of the e-government performance of the respective governments (Nkohkwo \& Islam, 2013).Lack of Information and Communication (ICT) infrastructure is one of the major challenges of E-government (Uddin, 2012; Kharel \& Shakya, 2012; Bhuiyan, 2011; Rupakheti \& Hashmati 2011; Dhami \& Futo, 2010). Without solid infrastructures, the aims of digital government cannot be achieved. Internetworking for sharing of information and opening up new channels for communication is a primary requirement, but is lacking in developing/under-developed countries (Dhakal, 2010; Alshehri \& Drew, 2010; Pavlichev, 2004).

Privacy and security concerns are additional serious issues associated with E-government advancement in developing countries (Dhakal, 2010; Dhami \& Futo, 2010; Im \& Seo, 2005; Baker \& Panagopolus, 2004). Privacy is a critical issue in the implementation of E-government in both developed and developing countries (Alshehri \& Drew, 2010). It refers to the strength of protection guarantees concerning information attributed to an individual. E-government is all about the digital collection of citizens' information such as name, address, property records, medical records, and employment history. Hence, citizens' confidence in the protection of privacy is highly essential but people fear to provide their true information because of potential misuse of their data (Alshehri \& Drew, 2010; Dhami \& Futo, 2010). Subsequently, many under-developed and developing countries also suffer from a digital divide problem (Alshehri \& Drew, 2010; Bhuiyan, 2011; Dhami \& Futo, 2010; Im \& Seo, 2005; Groper, 2004). Recent assessments of E-government efforts have found that governments are taking security and privacy much more seriously than they did in 2000 and 2001 (Baker \& Panagopoulos, 2004 quoted from West, 2000a; Larsen \& Rainie, 2002a). Different cyber-attacks, identity thefts, leakage of personal information etc. are of great concern.

Digital divide refers to the gap in between those who have access to the internet and those who do not (OECD, 2003). ${ }^{4}$ However, van Dijk and Hacker (2003) divided

4. In most of the literature, the digital divide is often discussed from the socio-economic aspect which focuses on the accessibility perspective of digital devices or the technology. As per this definition, it mentions the gaps between the people who have the chance and skills to access modern ICTs and those who do not. The digital divide has negatively affected the ability of minority groups to accumulate social capital (Groper, 2004). While the benefits of E-government applications and services are generally recognized, the use of these technologies occurs in a distressingly uneven manner (Baker \& Panagopoulos, 2004). For digital technologies to benefit everyone everywhere it is necessary to close the remaining digital divide, especially in internet access (WDR, 2016). Telephone, television, personal computers and the internet are largely included in this, however internet access is regarded 
the digital divide into two groups: the material digital divide (in terms of material access) and the usage digital divide (in terms of usage access). Strover (2003) also advanced the study of the digital divide problem from different directions. The afore-mentioned scholars have argued that even though public policies had largely been preoccupied with the material digital divide, presently the problem has shifted from the material to the usage digital divide. Hertz (2011), citing the Pew study (2010), has rightly raised the issue of a new understanding of the digital divide in her article. She writes that over the last ten years, access to technology has become more and more ubiquitous. She further mentions that the divide has shifted from an access issue to a kind of access divide (Hertz, 2011). Similarly, another issue associated with the digital divide in the present context is the issue of people with disabilities. Whatever technology has been developed or accessibility of digital devices made, the divide for these citizens has always been there. Sarson (2000) in his article also tried to define this issue differently. Quoting the statement of the then spokesman of the Liberal Democrats Vincent Cable, he writes, '... digital divide is not so much about wealth, but more about age and using adult education imaginatively.' Selwyn (n.d.) also advocated moving beyond the prevailing notions of a dichotomous 'digital divide' and 'access to ICT' towards a more elaborate and realistic understanding of inequalities in the information age. $\mathrm{He}$

at particularly important at the present time. This aspect of the explanation was more pronounced in the 90s or even in the 2000s. However, recently, a new discourse has been started on whether we can add more dimensions to define the digital divide that is "ability to use digital technology" or the digital divide because of usability: We are already in the digital era and by the end of 2016, at least $90 \%$ ( in fact, World Bank data shows that mobile cellular subscriptions are almost 98.65 in 2015) of the world population will be connected with some kind of digital technology (http://data.worldbank.org/indicator/IT.CEL.SETS.P2), nevertheless there are wide disparities among the population of choice in ability to use digital technology or digital services (for example South Korea has about $90 \%$ internet penetration and $40 \%$ fixed broadband, almost $100 \%$ has at least a $2 \mathrm{G}$ or above mobile subscription, nevertheless there are high disparities in activity on digital technology or other digital services. If we take the example of any advanced city we will find this type of digital divide. The third type of digital divide involves proficiency or level of expertise. In this type of digital divide all users have access of all kinds of digital technology with high usability, nevertheless the purpose for which the digital technology is used and proficiency in using digital technology also make a huge difference in the age of the digital revolution. For example, why do two competing candidates have different abilities to understand or expertise on the same digital technology even though they have been familiar with it for a long time. And another reason is that even in poor countries like Nepal, the accessibility of smart phones or even laptops is not the primary reason that people are deprived of using E-government services in remote villages; it is because of the lack of accessibility of infrastructures. 
suggested discussing four prominent areas of the digital divide debate (i.e. what is meant by ICT, what is meant by access, what is relationship between 'access to ICT' and 'use of ICT' and how can we best consider the consequences of engagement with ICT) to reconstruct the digital divide in more sophisticated terms.

In the same manner, the power crisis is another grave problem in developing countries (Dhami \& Futo, 2010; Uddin, 2012). Nepal is in the grip of an electricity crisis which began in 2006. In the last dry season, there was no electricity for 16 hours a day (Shrestha, 2010) and the Nepal Electricity Authority (NEA) had promised to end the load-shedding problem in the next five years. Unfortunately, the situation is still worsening. At present, Nepal is facing a 12 hours per day power cut problem (NEA, 2016) which is a normally unthinkable situation in rich nations.

\section{Political-Administrative Problems}

Recent studies have demonstrated that technology alone is not likely to affect efficiency or quality of services (Pavlichev, 2004). Alshehri \& Drew, (2010) citing Feng (2003) state that E-government is not a technical issue, rather an organizational issue. Unstable political situations where governments change frequently, resulting in the haphazard transfer of civil servants (Dhami \& Futo, 2010) are primarily responsible for the lack of preparation and proper execution of digital government. The frequent changing of officials as a result of changing governments hampers the continuity and effectiveness of running projects. Politics, as the pivot of all activities in any nation, substantially contributes to the environment in which a program is devised. In developing countries like Nepal, political instability becomes a primary problem for the proper implementation of E-government.

Similarly, incompetent and visionless leadership and the government's lack of will (Kharel \& Shakya, 2012; Uddin, 2012; Bhuyan, 2011; Dhakal, 2010) happens to be another major setback in this field. It is a common phenomenon that people in developing countries still have generally less technical know-how, and political leaders and government employees are not exceptions. When top political leaders and top bureaucrats are still traditional, then it is really hard to realize and implement the necessity of E-government.

In addition, lack of appropriate ICT policies and laws and their prompt execution (Uddin, 2012; Rupakheti \& Hashmati, 2011; Dhami \& Futo, 2010; Dhakal, 2010; Alshehri \& Drew, 2010) is another challenge in digital government development. Government commitment to develop the ICT sector in government and private organizations seems miserable. As a result, there is a lack of proper ICT policy and law. Archaic laws, old regulatory regimes, overlapping and conflicting authorities can all 
greatly complicate or altogether halt a project (Alshehri \& Drew, 2010). Last but not least, employees' resistance to change with the adoption of new technologies (AlShboul et al., 2014; Uddin, 2012; Dhami \& Futo, 2010; Pavlichev, 2004) is also equally responsible for the impediment of E-government execution. Traditional mind-set employees with the least technical and digital knowledge are often indifferent to using new systems at the workplace.

\section{Socio-cultural Problems}

Social and cultural practices of any country are also responsible for hindering the development process of any particular sector. Illiteracy and lack of ICT education (AlShboul et al., 2014; Uddin, 2012; Kharel \& Shakya, 2012; Bhuiyan, 2011; Rupakheti \& Hashmati, 2011; Dhakal, 2010; Dhami \& Futo, 2010) is still a primary problem in most under-developed and developing countries. For example, the average literacy rate of Nepal is just 65.9 percent, with a male literacy rate of 75.1 percent and a female literacy rate of 57.4 percent (CBS, 2012). Besides, education related to information and technology is even more miserable.

Additionally, inadequately skilled human resources (Uddin, 2012; Kharel \& Shakya, 2012; Bhuiyan, 2011; Rupakheti \& Hashmati, 2011; Dhakal, 2010; Dhami \& Futo, 2010; Alshehri \& Drew, 2010) is another serious issue in the implementation of digital government in poor countries. The lack of qualified staff and adequate training in developing countries (Nkohkwo \& Islam, 2013) has always been a problem for the success of ICT in governments. Heeks (2002) stresses that the factors influencing the success of ICT implementation tend to be 'situation specific' or 'contingent.' He again claims that the 'design-reality gap' is a danger where the tool and the task may misfit.

Lack of e-governance awareness (Al-Shboul et al., 2014; Kharel \& Shakya, 2012; Uddin, 2012; Bhuiyan, 2011; Dhami \& Futo, 2010) seems to be another challenge to the success of ICT implementation in developing and third world nations. Al-Jaghoub, Al-Yaseen and Al-Hourani (2010), Rupakheti and Hashmati (2011) and Dhakal (2010) also reiterate that awareness of E-government did not reach the required level. Banda (2012), mentioning the case of Zambia, wrote that the overall E-government project implementation rating score is 55.10 based on Heeks' 100-point scale, which denotes that projects partially or totally failed. Banda further mentioned that awareness of Egovernment projects was found to be inadequate.

Rampant corruption (Bhuiyan, 2011; Dhami \& Futo) is also another worrisome issue especially in case of poor countries. Transparency International defines corruption as, "The abuse of entrusted power for private gain." According to the Corruption Perceptions Index (2015), Nepal scores 27 out of 100 and falls in 130th place out of 
168 countries in the world. Seo and Hasan (2016) mention that corruption is the greatest obstacle for economic and social development in developing countries and their empirical analysis verifies that corruption decreases when the use of ICT in government increases.

It is obvious that it's tough to implement a project so technical in nature if the majority of people are either illiterate or just literate and have less technical know-how. Another hard fact is the availability of highly skilled manpower in Nepal in term of ICT development. The aim of an IT strategy for government should be heavily rooted in the idea of enhancing human interactions and forming alliances within and external to a department, bringing new perspectives and incorporating opposing values (Allen, Juillet, Miles, Paquat, Roy \& Wilkins, 2004). In the third world corruption is one of the principal impediments for governance (Iqbal \& Seo, 2008). When society acknowledges and hails to rich peoples, then politicians, bureaucrats and other concerned people become involved in illegal activities like graft. As a result, the quality of work and stipulated targets never happen in time. The remedy for corruption in the government sector is again E-government. E-governance is an effective anti-corruption tool (Iqbal \& Seo, 2008). They further mention that corruption is a kind of habit and E-government can change that habit.

\section{Economic Problems}

The economic part of E-government development is another notable issue. Transforming a government from traditional to modern requires a sufficient endowment. In under-developed countries like Nepal there is the problem of insufficient funding (AlShboul et al., 2014; Kharel \& Shakya, 2012; Uddin, 2012; Rupakheti \& Hashmati, 2011; Dhami \& Futo, 2010,). In addition to the funding issues, there is another problem of sustainability (Uddin, 2012; Dhami \& Futo, 2010). Even if a project is started and launched with the help of donor agencies, there remains the problem of operation and maintenance for a long time. As a result, such projects often face an untimely demise. In the same way, low per capita income (Kharel \& Shakya, 2012; Dwivedi \& Sahu, nd.) is another economic problem in the case of Nepal. The per capita income of Nepal is just $\$ 730$ (World Bank, 2014) at present which signifies that the mass of people is still out of the reach of modern ICTs. The Gross Domestic Product (GDP), which is another way to measure the financial strength of an economy, is also just $\$ 19.77$ billion at market prices (World Bank 2014). 


\section{RESEARCH FRAMEWORK}

In pursuance of our analysis of the current situation of E-government in Nepal, United Nations E-government survey data were used. Time series data, starting from its inauguration in 2003 to the latest one in 2014, were collected, tabulated and presented graphically in accordance with their necessity and appropriateness. For the purpose, the situation of Nepal's E-government is compared with other SAARC countries. As it is unequivocal that the current situation of Nepal in this regard is abysmal in comparison to developed nations, we intend to see it from SAARC nations' perspective. The biennial edition of the United Nations E-government survey aims to exemplify successful Egovernment strategies, pioneering practices with a view towards administrative reform and sustainable development (United Nations, 2014). From its commencement in 2001, the conceptual framework of the E-government Development Index (EGDI) remains unchanged. And its methodological framework, which is based on a holistic view of E-government development, has also remained consistent across survey periods. The reason why we adopted UN E-government Survey data is that this is the only universally recognized and accepted comprehensive report evaluating the status of $\mathrm{E}$ -

Figure 5. Research Framework

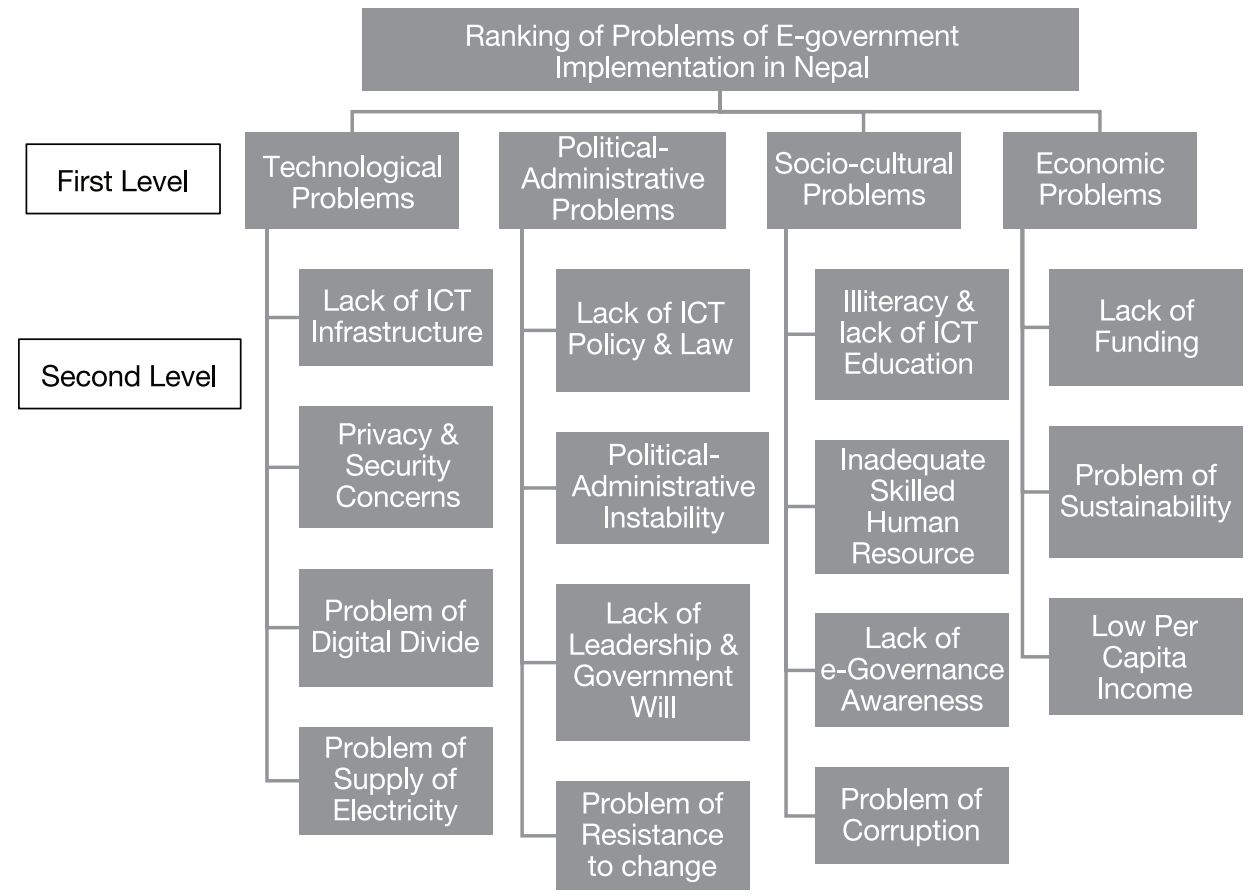


government of all 193 member countries of the United Nations. With the help of this report, decision-makers of all nations are able to identify the real situation of E-government initiatives and weaknesses and obstacles. It is commonly used to inform E-government planning and strategy, implementation and execution (Seo \& Hasan, 2015).

A comprehensive review of relevant literature was carried out to find the major problems of E-government implementation. Although all the problems stated in the past literature were mentioned arbitrarily, we have tried to manage them under certain categories in a logical order. By doing so, four major categories and their related problems were identified and classified accordingly. After discussion of some major problems categorically in the above section, we here now try to shape them in a framework.

For the AHP analysis, data were collected from 25 experts. ${ }^{5}$ Out of them, 10 were top level bureaucrats (i.e. secretary, joint-secretary and under-secretary) of the Nepal government. Similarly, the number of academic and private sector experts were 10 and 5 respectively. A systematic questionnaire with detailed information was prepared. Initially, the respondents were requested via email and/or Facebook messenger to take their prior consent why they were chosen and why they were an important part for the accuracy and analysis of the study. These 25 experts were chosen purposively among three strata based on their knowledge, experience and skill as mentioned in footnote 4. By choosing them, we expect that their responses truly indicate the ranking of the problems of E-government implementation in Nepal. The ranking of implementation problems of E-government in Nepal was done using the Analytic Hierarchy Process (AHP) first developed by Thomas L. Saaty in 1970s. AHP- a multi-criteria decision making approach in which factors are arranged in a hierarchic structure (Saaty, 1990). In using the AHP to model a problem, one needs a hierarchic or a network structure to represent that problem and pairwise comparisons to establish relations within the structure (Saaty, 1987). The expert choice software was used for data analysis. The inconsistency ratio of the different groups of respondents and overall was less than 0.02 .

5. As this research aims to take the help of experts' opinion to rank the problems of E-government implementation in order, their selection was based on a stratified sampling method. Data were collected from three different strata (i.e. top level bureaucrats, professors and private sector executives). A purposive sampling - a non-probability sampling method; which is also known as judgmental or subjective sampling, was also employed. A broad range of criteria were set based on educational background, work experience, involvement with ICT-related activities, social media participation and interaction, familiarity with public policies etc. for the selection of the respondents. Additionally, we also tried to see whether there is a difference of opinions between or among the three groups of experts, however, no such distinction was found in the analysis of data. Almost all experts, whether government bureaucrats or others, mentioned the same issue as stated in the analysis below. 
Based on the above research framework, fifteen problems within four categories were identified and data obtained from twenty-five respondents were entered in software and analyzed. The results obtained from the data analysis are presented under the different headings in the findings section as follow.

\section{FINDINGS}

\section{First Step for Finding Problems}

\section{Ranking of Four Main Categories of Problems of E-government Implementation in Nepal}

First and foremost, we tried to analyze the main categories of problems. Out of the four major categories of the problems, surprisingly, the political-administrative dimension has been placed as the major problem of E-government implementation in Nepal. Before the analysis of data, we regarded digital government d chiefly as a technological aspect of government, and thought that experts would prioritize technological dimensions, but surprisingly they placed the political-administrative dimension of problems at the first place. The analysis of data reveals that political-administrative problems carry $46.3 \%$ followed by socio-cultural problems (20.0\%) and technological problems $(18.6 \%)$. The experts have placed economic-related problems at the last place with the value of $15.1 \%$.

One assistant professor at Purbanchal University (PU) and researcher who is highly active in social media says,

"I think the apex problem regarding E-government in Nepal is the lack of political leadership and stability. If the stability is prevailed by the leadership then law derivation and implementation is successful. Once the law is implemented,

Figure 6. Ranking of Main Problems of E-government Implementation in Nepal

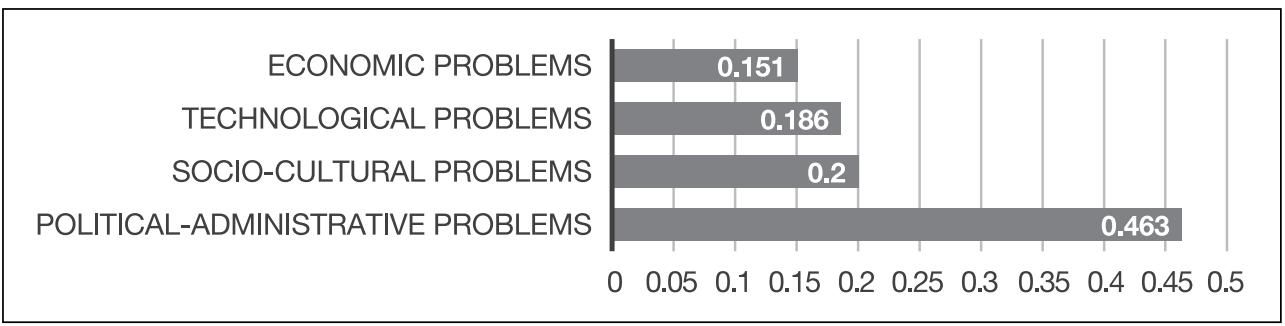


humans have tendency to optimize and learn. The change in leadership I believe will still take time."

Answering an open-ended question about whether we can change the above mentioned barriers in the future, another respondent who is serving as project manager in a big company and is also a senior engineer in Nepal also substantiates the afore-mentioned statement as,

"Yes, we can change the barriers in future but it will require overall change in administrative structures and young e-friendly leadership in the country. Present bureaucracy and political leadership in Nepal is inefficient, corrupt, non-transparent, irresponsible and orthodox. So tech-savvy, educated and farsighted leadership in both bureaucracy and politics is an essence of present time to restructure our government and its administrative system."

In this regards, experts think political and administrative related problems are the most severe ones of all. However, some experts have emphasized technological-related issues also as a grave problem. In this regard, a top bureaucrat who is the secretary of the Nepal Government put forwarded his view in the following way,

"Majority of top-level bureaucrats and political leaders are still unaware about the power of ICTs. Government system does not have sufficient ICT experts in house. All government organizations are primarily dependent on private organizations and these outsourced are not sustainable and long lasting in Nepal. And again, the power crisis is totally hampering overall administrative activities in the country."

\section{Second Step for Finding Problems}

\section{Results of Problems within Each Category}

Problems within each category were also calculated which are presented in the following figures. In the Political-Administrative category, there were four problems included. After analyzing within the political-administrative category, we obtained the following result.

Within the Political-Administrative category of problems, lack of leadership and government will has obtained first place with $36.7 \%$ followed by political-administrative instability $(34.0 \%)$, the problem of resistance to change $(20.8 \%)$ and lack of ICT policy and law (8.5\%). This results shows that because of a lack of visionary leadership 
Figure 7. Ranking of Political-Administrative Problems

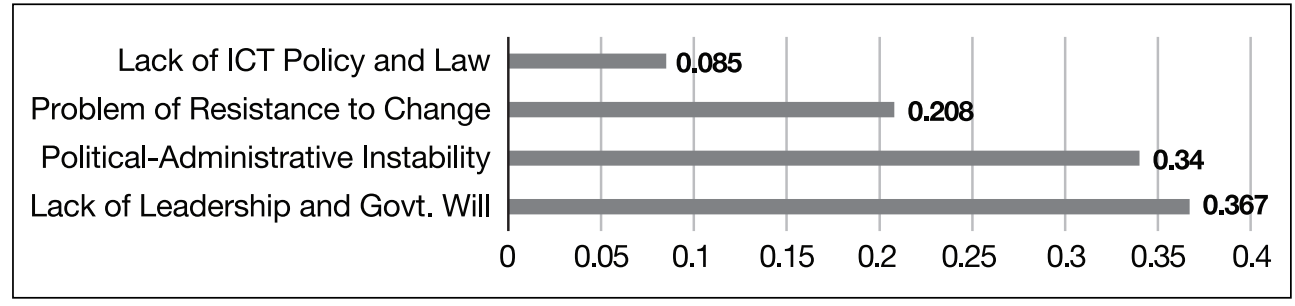

in political and administrative sectors and instability, it is becoming hard to implement E-government related activities in the country.

Considering the socio-cultural category of problems, the problem of corruption was rated as the highest issue with $35.1 \%$. Inadequately skilled human resources and illiteracy \& lack of ICT education were equally rated with $24.4 \%$ and $23.0 \%$ respectively. Though lack of e-governance awareness was placed last, it also carries $17.6 \%$.

Figure 8. Ranking of Socio-Economic Problems

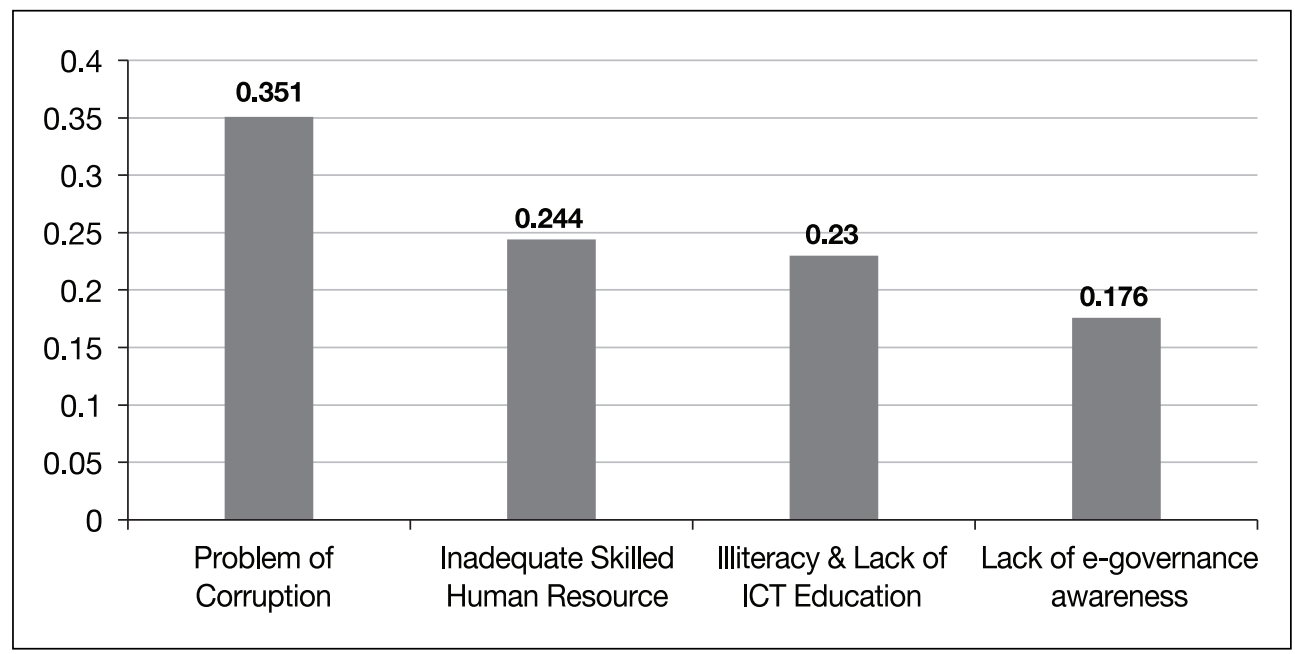

Viewing E-government as digital government, our initial expectation before the analysis of the survey data was that it is more of a technological problem. So problems associated with technological issues would get a top priority. However, this was not the evaluation of experts. Within the technological category of problems, experts have placed "lack of ICT infrastructure" at the first place with 41.6\%. The problem of "lack of supply of electricity" (37.6\%) was another notable issue. The problem of digital 
Figure 9. Ranking of Technological Problems

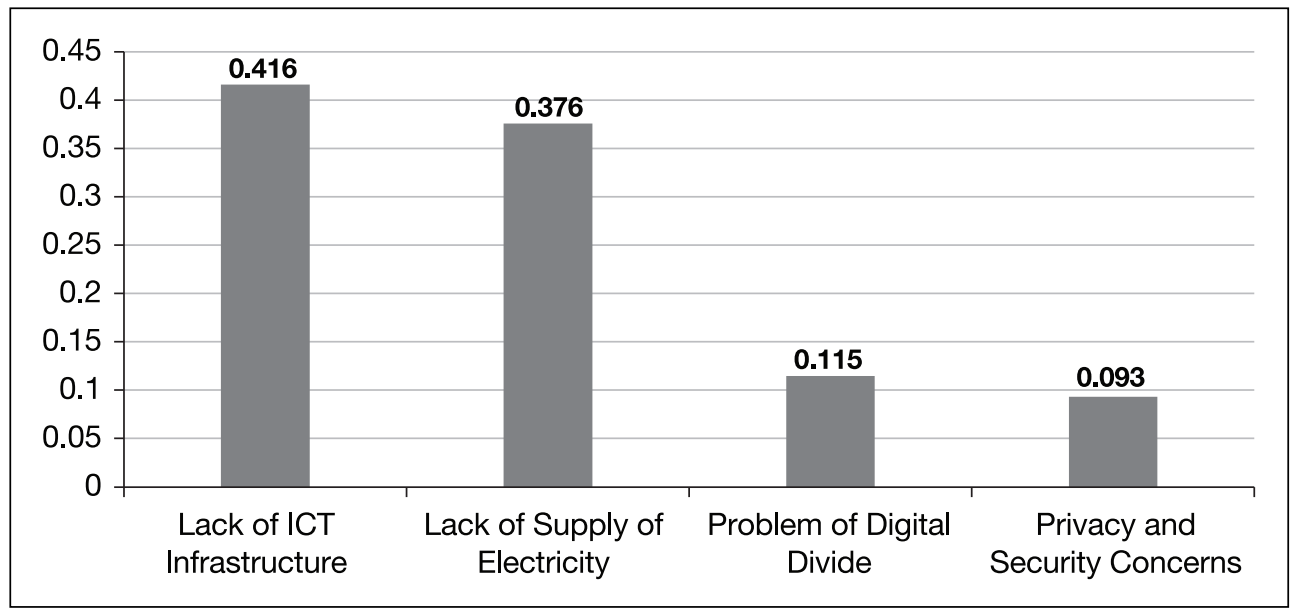

divide (11.5\%) and privacy and security concerns (9.3\%) were less emphasized.

Economy-associated problems are also major problems in the case of poor countries like Nepal. There were three main problems placed in this category. Within the economic category of problems of E-government implementation in Nepal, experts have rated the problem of sustainability at the top with $47.2 \%$. Similarly, the issue of lack of adequate funding has also been recognized as one of the influential problems with $33 \%$. Low per capita income carries less than $20 \%$ among them.

Figure 10. Ranking of Economic Problems

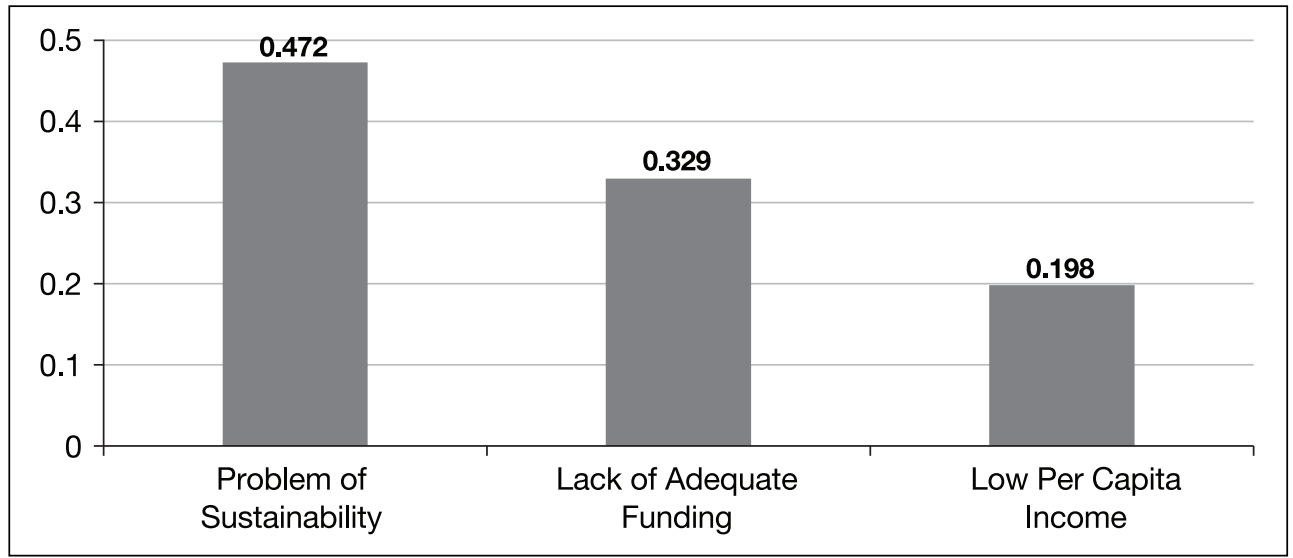




\section{Results of Overall Ranking of Problems and their Respective Weights}

The final and main work of data analysis was the overall ranking of problems and their respective weights. Among fifteen individual problems included in this questionnaire, the following results show their ranking with face value. At the last stage, the results of the overall weights of problems have been calculated by multiplying the weight of the respective category and the priority weight of each problem. Overall, the experts have rated the problem of leadership and government will (17.8\%) as the most severe problem. Two other problems namely; political-administrative instability (16.5\%) and the problem of resistance to change $(10.1 \%)$ have also been placed in second and third place. Six other problems from the problem of corruption to illiteracy \& lack of ICT education have been placed as medium level problems with ratings less than $10 \%$ and more than $5 \%$. Similarly, the problem of the digital divide (2\%) and privacy and security concerns $(1.6 \%)$ were the least prioritized issues among all.

Figure 11. Overall Ranking of E-government in Nepal

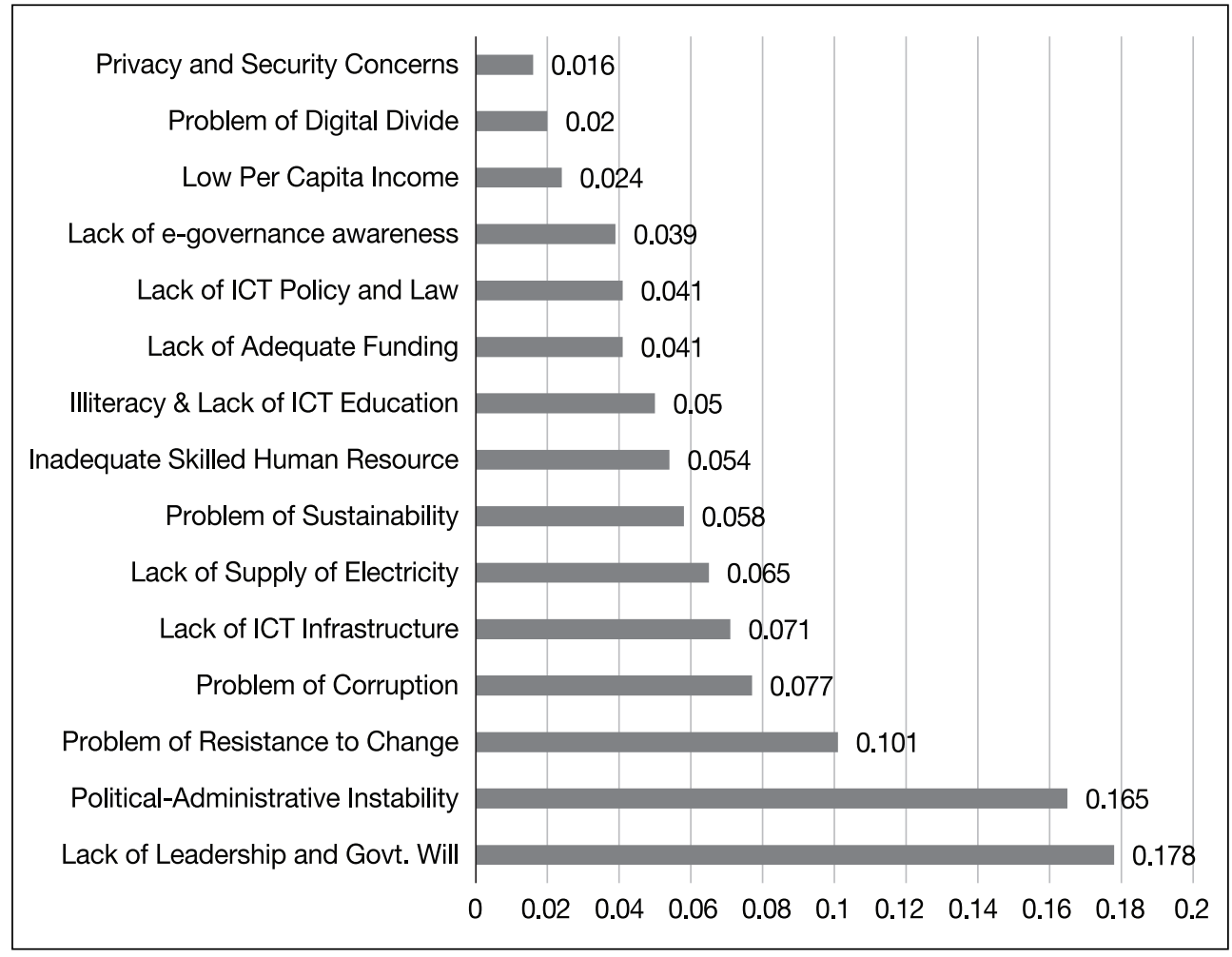


One respondent who is the CEO of a private company with long years of working experience at home and abroad has responded to an open-ended question in the following manner,

"The constant change in leadership in Nepal is a manifestation of political turmoil and instability which has now gone on for at least a decade. Political stability is rudimentary to achieving e-governance as developing an IT system ... Not all leaders have the capacity to understand or even think of improving governance using electronic mediums and when certain leaders who do come into power, it is unfortunate that they do not carry on long. In the case of Nepal, without a doubt it is political instability and lack of coherent leadership that has impacted e-governance implementation."

\section{CONCLUSION, RESEARCH IMPLICATIONS AND LIMITATIONS}

The history of Nepalese E-government is still young. After the restoration of democracy in 1990, Nepal observed notable improvements and changes in the IT sector, particularly during 1997-2004, which happened to be an important time when a number of policy and regulatory measures were prepared and implemented in the ICT sector (Rupakheti \& Hashmati, 2011). Analyzing UN E-government survey data, the current situation of Nepal is very poor where the world average of EGDI in 2014 was 0.4712 and Nepal's value was 0.2344 with a rank of 165 th. In terms of e-participation ranking, the situation of Nepal is also inconsistent. In 2003, Nepal was placed in the 61st position. This ranking plunged to 152nd in 2008 and in 2014, Nepal stands in 110th place.

Despite some positive initiatives taken by the Government of Nepal in the course of E-government improvement, there remain many problems and these problems are categorized into four divisions, namely: technical, political-administrative, social-cultural and economic. Altogether 15 problems of E-government implementation in Nepal were identified out of which three problems, namely; the problem of leadership and government will (17.8\%), political-administrative instability (16.5\%) and the problem of resistance to change $(10.1 \%)$ were again highlighted as the most severe ones by the experts using the Analytic Hierarchy Process method. Frequently changing governments (for example, 25 different governments i.e. 17 from 1990-2008 and 8 from 2008- present, have been formed in Nepal in the last 25 years) is a clear indication of political instability. It is a common parlance that when politics, which is a pivot around 
which all other activities cluster, gets volatile, other sectors in the economy get distracted. Hence, the experts also supported the above mentioned fact and voted $45 \%$ importance to the political-administrative related problems. Hence, it can be suggested that though E-government itself is largely a technological issue of development, political-administrative reform is realized to be the top priority. Needless to say, as soon as the politicaladministrative stability and visionary leadership accepting change is maintained, other sectors [improvements] like the development of E-government in the country will happen naturally.

Theoretically this research confirms that all the E-government implementation related problems cited in the past literature are also major problems with reference to Nepal. Furthermore, this study has acknowledged all the relevant issues in developing countries and managed them in a more systematic and scientific order. So, it will be easier for future researchers to use this research framework for their studies.

The practical aspect of the research is that-Nepal, still an economically least developed country, lacks plentiful resources to invest in different developmental works. As there is a scarcity of necessary resources and required technology, Nepal cannot solve all problems at a time. The failure of the E-government Master Plan; 2007-11 (Rupakhetee \& Hashmati, 2011) is one of the apparent examples. Hence, by comparing the major problems, we hope that it gives a guideline to rank the problems in order. As a result, it will give a guideline to the political leaders, top bureaucrats and other concerned academicians and policy analysts to solve the problems of E-government implementation in Nepal in a hierarchical order.

However, this study adopts only the AHP method of analysis. In addition to the AHP method, a more extensive and interactive interview method also could be better. Although we asked some open ended questions to know their personal opinions, we did not include all of them here because the purpose of present study is only to rank problems in hierarchical order using AHP. So in future research we will have to look deeper on that part too. Similarly, the method of study was to use AHP by taking the help of experts' opinions, however, only 25 respondents were selected from the three different categories. It would certainly be better and more justifiable if we selected a larger number of responses.

\section{REFERENCES}

Allen, B., Juillet, L., Miles, M., Paquet, G., Roy, J. \& Wilkins, K. 2004. The organizational culture of digital government: Technology, accountability \& shared governance. In A. Pavlichev and G. D. Garson (eds.), Digital government: Principles and 
best practices. Hershey, PA: Idea Group Publishing.

Al-Jaghoub, S., Al-Yaseen, H. \& Al-Hourani, M. 2010. Evaluation of awareness and acceptability of using e-government services in developing countries: The case of jordan. The Electronic Journal Information Systems Evaluation, 13(1): 1-8.

Al-Shboul, M., Rababah, O., Al-Shboul, M., Ghnemat, R. \& Al-Saqqa, S. 2014. Challenges and factors affecting the implementation of e-government in jordan. Journal of Software Engineering and Applications, 7: 1111-1127. Retrieved on January 3, 2016, from http://dx.doi.org/10.4236/jsea.2014.713098.

Alshehri, M. \& Drew, S. 2010. E-government fundamentals. IADIS international conference ICT, society and human beings. School of ICT, Griffith University, Brisbane, Australia.

Baker, P. M. A \& Panagopoulos, C. 2004. Political implication of digital (e-) government. In A. Pavlichev and G. D. Garson (eds.), Digital government: Principles and best practices. Hershey, PA: Idea Group Publishing.

Banda, S. 2012. Success and failure of e-government projects in developing countries: The case of Zambia. Unpublished Masters' Thesis in Global Information and Telecommunication Technology Program, School of Innovation, KAIST, South Korea.

Bauer, R. 2016. Media R(evolutions): Dramatic speed of internet, mobile phones not enough to get women online. World Bank. Retrieved on May 2, 2016, from http://blogs.worldbank.org/category/tags/digital-divide.

Bhuiyan, S. H. 2011. Modernizing Bangladesh public administration through e-governance: Benefits and challenges. Government Information Quarterly, 28: 56-65.

CBS (Central Bureau of Statistics). 2012. National population and housing census 2011. Kathmandu: CBS.

Constitution of Nepal. 2015. Constitution Drafting Committee; Constituent Assembly Secretariat, Kathmandu, Nepal.

CPI (Corruption Perceptions Index). 2015. Transparency international. Retrieved on May 5, 2016 from https://www.transparency.org/country/\#NPL.

Dhakal, T. N. 2010. E-governance in Nepal: Prospects and challenges. Central Department of Public Administration, Tribhuvan University, Kathmandu Nepal.

Dhami, D. B. \& Futo, I. 2010. Implementation challenges of e-governance in Nepal and possible steps towards solutions. Proceedings of the 8th International Conference on Applied Informatics. Eger, Hungary, January 27-30, 2010. 1: 433-445.

Dwivedi, P. \& Sahu, G. P. (nd.). Challenges of e-government implementation in India. School of Management, Krishna Institute of Engineering and Technology, Muradnagar, Ghaziabad, India.

Groper, R. 2004. Digital government and the digital divide. In A. Pavlichev and G. D. 
Garson (eds.), Digital government: Principles and best practices. Hershey, PA: Idea Group Publishing.

Heeks, R. 2002. E-government in Africa: Promise and practice. Institute for the Development Policy and Management, Paper No. 13, University of Manchester, the UK. Retrieved on April 2, 2016 from http://idpm.man.ac.uk/wp/igov/index.htm.

Hertz, M. B. 2011. A new understanding of digital divide. Edutopia. Retrieved on December 4, 2016 from https://www.edutopia.org/blog/digital-divide-technologyinternet-access-mary-beth-hertz.

Im, J. J. H. \& Seo, J. W. 2005. E-government in South Korea: Planning and implementation. Electronic Government: An International Journal, 2(2): 188-204.

Iqbal, M. S. \& Seo, J. W. 2008. E-governance as an anti-corruption tool: Korean cases. Journal of Korean Association for Regional Information Society, 11(2): 51-78.

Joshi, N. L. 1973. Evolution of public administration in Nepal: Experiences and lessons. Kathmandu: Centre for Economic Development and Administration.

Kharel, P. \& Shakya, S. 2012. E-government implementation in Nepal: A challenges. International Journal of Advanced Research in Computer Science and Software Engineering, 2(1): 1-11.

Lupilya, E. C. \& Jung, K. 2015. E-government transformation in Tanzania: Status, opportunities and challenges. The Korean Journal of Policy Studies, 30(1): 147184.

MOGA (Ministry of General Administration), Government of Nepal. 2015. Retrieved on November 7, 2015, from http://www.moga.gov.np/main/index.php/actsregulations.

MoST (Ministry of Science and Technology). 2010. Information technology policy, 2010. Kathmandu: MoST.

MoSTE (Ministry of Science, Technology and Environment). 2000. Information technology policy, 2000. Kathmandu: MoSTE.

NEA (Nepal Electricity Authority). 2016. Retrieved on May 3, 2016, from http://www. nea.org.np/loadshedding.html.

Nkohkwo, Q. N. \& Islam, M. S. 2013. Challenges to the successful implementation of e-government initiatives in sub-saharan Africa: A literature review. Electronic Journal of e-Government, 11(2): 253-25.

NT (Nepal Telecom). 2015. Retrieved on November 13, 2015, from https://www.ntc.net. np/companyInfo/ntBrief.php accessed on 13/11/2015.

NTA (Nepal Telecommunication Authority). 2015. Retrieved on November 13, 2015, from http://www.nta.gov.np/ne/about-us-2.

OECD, OECD E-government Flagship Report 2003. The e-government imperative. Public Management Committee. Paris: OECD. 
Pavlichev, A. 2004. The e-government challenge for public administration education. In A. Pavlichev and G. D. Garson (eds.), Digital government: Principles and best practices. Hershey, PA: Idea Group Publishing.

Poudyal, S. R. 2009. Dynamics of formal \& informal institutes shaping the administrative culture: A case of Nepalese public administration. Unpublished Master's Thesis in Development Studies (PPM), International Institute of Social Science (ISS), The Hague.

Rupakhetee, K. \& Heshmati, A. 2011. Rhetorics vs. realities in implementation of e-government master plan in Nepal. Technology Management, Economics, and Policy Program (TEMEP Discussion Paper No. 2011:75) Seoul National University.

Saaty, R. W. 1987. The analytic hierarchy process-What it is and how it is used. Mathl Modeling, 9(3-5): 161-176.

Saaty, T. L. 1990. How to make a decision: The analytic hierarchy process. European Journal of Operational Research, 48: 9-26.

Sarson, R. 2000. IT on the fringe 2000-Liberal democrats @ bournemouth. The Source Public Management Journal, 19th September. Retrieved on December 5, 2026 from http://www.sourceuk.net.

Selwyn, N. (n.d.). Defining the 'digital divide': Developing a theoretical understanding of inequalities in the information age. Adults learning @ home-An ESRC funded research project, Occasional Paper 49. Retrieved on December 3, 2016, from http://www.cardiff.ac.uk/socsi/ict.

Seo, J. W. \& Hasan, M. G. M. 2015. Where are e-governments in South Asian countries? South Asian Studies—A Research Journal of South Asian Studies, 30(2): 7-18.

Seo, J-W. \& Hasan, M. G. M. 2016. E-government efforts against corruption in Bangladesh: What we have done and what we have to do. International Journal of Political Science \& Diplomacy, 1: 107. doi: http://dx.doi.org/10.15344/ijpsd/ 2016/107.

Shrestha, R. S. 2010. Electricity crisis (load shedding) in Nepal, its manifestations and ramifications. Hydro Nepal, 6: 7-17.

Strover, S. 2003. Remapping the digital divide. The Information Society, 19: 275-277.

Uddin, G. 2012. E-governance of Bangladesh: Present scenario, expectation, ultimate target and recommendation. International Journal of Scientific and Engineering Research, 3(11).

United Nations. 2014. E-government survey, 2014.

United Nations. 2012. E-government survey, 2012.

United Nations. 2010. E-government survey, 2010.

United Nations. 2008. E-government survey, 2008. 
United Nations. 2005. E-government survey, 2005.

United Nations. 2004. E-government survey, 2004.

United Nations. 2003. E-government survey, 2003.

UNASPA (United Nations and American Society for Public Administrations). 2001. Global survey of e-government. Asia Oceania E-business Marketplace Alliance. van Dijk, J. \& Hacker, K. 2003. The digital divide as a complex and dynamic phenomenon. The Information Society, 19: 315-326.

World Bank. 2002. The e-government handbook for developing countries: A project for information for development program \& the center for democracy \& technology. Washington D.C.: WB.

World Bank. 2014. World bank data. Retrieved on January 26, 2016, from http://data. worldbank.org/country/nepal.

World Development Report. 2016. Digital dividends. Washington D.C.: World Bank. 